\title{
Lancelot Voisin de La Popelinière, L'Histoire de France. Tome III (1561-1562)
}

\section{Maurizio Busca}

\section{(2) OpenEdition}

1 Journals

\section{Edizione digitale}

URL: https://journals.openedition.org/studifrancesi/21091

DOI: 10.4000/studifrancesi.21091

ISSN: 2421-5856

\section{Editore}

Rosenberg \& Sellier

\section{Edizione cartacea}

Data di pubblicazione: 1 décembre 2019

Paginazione: 563

ISSN: 0039-2944

\section{Notizia bibliografica digitale}

Maurizio Busca, «Lancelot Voisin de La Popelinière, L'Histoire de France. Tome III (1561-7562)», Studi Francesi [Online], 189 (LXIII | III) | 2019, online dal 01 mars 2020, consultato il 11 novembre 2021. URL: http://journals.openedition.org/studifrancesi/21091; DOI: https://doi.org/10.4000/studifrancesi. 21091

Questo documento è stato generato automaticamente il 11 novembre 2021.

\section{(c)}

Studi Francesi è distribuita con Licenza Creative Commons Attribuzione - Non commerciale - Non opere derivate 4.0 Internazionale. 


\title{
Lancelot Voisin de La Popelinière, L'Histoire de France. Tome III
}

\author{
(1561-1562)
}

\author{
Maurizio Busca
}

\section{NOTIZIA}

Lancelot Voisin de La Popelinière, L'Histoire de France. Tome III (1561-1562), édition critique par P.-A. Mellet et $\mathrm{O}$. Turias sous la direction de D. Turrel, Genève, Droz, 2019, «Travaux d'Humanisme et Renaissance» 595, 539 pp.

1 L'edizione critica della monumentale Histoire de France di La Popelinière giunge al terzo tomo, che contiene i libri VII e VIII e riporta gli avvenimenti occorsi tra la fine del 1560 e la fine del 1562. Ricordiamo che il cui primo tomo, apparso nel 2011, riunisce i libri IIV preceduti da un'introduzione generale (si veda la segnalazione di M. Mastroianni apparsa nella Rassegna bibliografica del n.166, p.135), mentre il secondo tomo, pubblicato nel 2016, riunisce i libri V-VI. Il presente volume copre il periodo che precede immediatamente lo scoppio delle guerre di religione e la fase iniziale del primo conflitto, che l'A. ripercorre attingendo ampiamente ai lavori storiografici disponibili (La Planche, La Place, Bèze) ma arricchendo il testo di numerosi documenti. Benché l'adesione dell'A. alla causa ugonotta emerga chiaramente, l'opera non assume i caratteri di una narrazione partigiana della storia: come segnala l'editore P.-A. Mellet nella sua nota introduttiva, «La Popelinière considère que les "affaires d'Estat et de guerres" sont souvent opposées à "celles de la religion”» (p. 4). 